\title{
On the Genesis and Function of Coccolithophore Calcification
}

\author{
Marius N. Müller* \\ Department of Oceanography, Federal University of Pernambuco, Recife, Brazil
}

Keywords: coccolithophore, coccolith, biomineralization, calcifying phytoplankton, evolution, marine calcification

OPEN ACCESS

Edited by:

Xinping $\mathrm{Hu}$,

Texas A\&M University Corpus Christi,

United States

Reviewed by:

Alberto G. Sáez,

University of Zurich, Switzerland

Michaël Hermoso,

UMR7193 Institut des Sciences de la Terre Paris (ISTEP), France

*Correspondence:

Marius N. Müller mariusnmuller@gmail.com

Specialty section: This article was submitted to Marine Biogeochemistry, a section of the journal

Frontiers in Marine Science

Received: 23 November 2018

Accepted: 29 January 2019

Published: 15 February 2019

Citation:

Müller MN (2019) On the Genesis and Function of Coccolithophore

Calcification. Front. Mar. Sci. 6:49. doi: 10.3389/fmars.2019.00049
The functional group of coccolithophores consists of calcifying eukaryotic unicellular phytoplankton that produces minuscule $\mathrm{CaCO}_{3}$ structures, named coccoliths, surrounding the cell, and forming a coccosphere. Coccolithophores occupy an important role in carbon cycling dynamics over short and geological time scales due to the process of calcification fuelled by photosynthetic energy. The precipitation of $\mathrm{CaCO}_{3}$ in the euphotic zone, the subsequent vertical export, and ballast effect for organic matter can significantly influence the exchange of carbon dioxide between the surface ocean and the atmosphere (Sanders et al., 2010). The sediment record of coccoliths dates back to the Late Triassic (Bown et al., 2004), and the geochemical composition of coccoliths offers a potential paleoproxy to reconstruct past environmental conditions (Hermoso, 2014; McClelland et al., 2017; Müller et al., 2018).

Since the discovery that coccoliths are of biological origin (Sorby, 1861), the general understanding of coccolithophore calcification has substantially increased and the underlying calcium carbonate precipitation kinetics and the cellular mechanisms involved have been partly revealed (e.g., Mackinder et al., 2011; Mejía et al., 2018). Coccolithophores demonstrate a diverse range of trophic modes (auto-, hetero-, and mixotrophic) and have a haploid-diploid life cycle with asexual reproduction present in both life cycle stages (von Dassow and Montresor, 2011; Thomsen and Østergaard, 2015). The coccoliths precipitated in the haploid and diploid phase have distinct morphologic and crystallographic features and have been categorized in holoand heterococcoliths, respectively (Young and Henriksen, 2003). While the majority of the approximately 200 coccolithophore species bear distinct $\mathrm{CaCO}_{3}$ structures in both life cycle stages, molecular data, environmental surveys, and culture studies revealed cases of non-calcifying, partly calcifying, and heterogeneously calcifying coccolithophore cells (e.g., de Vargas et al., 2007). Over the past two decades, the process of calcification in coccolithophores has received increased attention due to ongoing anthropogenic ocean acidification and the associated elevated energy demand for marine calcifiers to build their $\mathrm{CaCO}_{3}$ structures (e.g., Hofmann et al., 2010). The overall conducted research has led to an impressive set of literature and a series of reviews are available covering various aspects of coccolithophore biology and ecology (e.g., Paasche, 2001; Brownlee et al., 2015; Taylor et al., 2017; Balch, 2018).

One main challenge in coccolithophore evolution and ecology is to understand the possible functions and benefits of intracellular calcium carbonate precipitation. Several hypotheses have been put forward to explain the cellular benefits and the resulting competitive ecological advantages of coccolith production. The proposed hypotheses suppose protective functions against grazing, intense solar/UV radiation, virus attacks, and benefits for photosynthesis due to light bundling or carbon concentrating mechanism (see for example Young, 1994; Raven and Crawfurd, 2012; Monteiro et al., 2016). The increasing diversity of possible functions is clearly beneficial for the scientific community, incentivizing discussion, and experimental assessment. However, up to date 
none of the proposed hypothesis has been supported by sufficient and consistent evidence to be developed into an accepted scientific concept. The majority of hypotheses is discussing benefits of coccolithophore calcification regarding modern ocean chemistry and ecological settings. The appearance of fossil coccoliths, however, dates back to about $225 \mathrm{Ma}$ (Bown et al., 2004) under quite different environmental settings. Here, I would like to illustrate the necessity to differentiate possible functions and benefits of $\mathrm{CaCO}_{3}$ precipitation under modern ecological settings from the historical benefits at the time of genesis and development.

Recently, Monteiro et al. (2016) revisited and critically assessed several hypotheses of coccolithophore calcification, modeling their energetic costs, and ecological benefits. The authors concluded that (1) the energy demanding process of calcification presumably evolved initially to reduce grazing pressure and (2) additional benefits of calcification contributed to the diversification of coccolithophore morphology and ecological niche habitats. A protective function of a coccosphere to reduce grazing pressure can act in several ways: (a) creating a physical barrier that protects against predators' feeding tubes (peduncles) and subsequent myzocytosis, (b) preventing/reducing grazer ingestion and/or phagocytosis by extended $\mathrm{CaCO}_{3}$ structures, (c) reducing the nutritional benefits gained in comparison to non-calcified phytoplankton species, and (d) causing an indirect predator poisoning by elevated concentrations of internal dissociated calcium due to the consumption of high $\mathrm{CaCO}_{3}$ to organic matter ratios (Harvey et al., 2015). The first two mechanisms directly reduce the active grazing pressure, while the latter two forms induce a positive feedback for coccolithophore populations due to reduced fitness/reproduction of the grazing population. The highest efficiencies of these mechanisms are achieved when the surrounding coccosphere is completed and/or sufficient $\mathrm{CaCO}_{3}$ has been accumulated in relation to organic matter.

It is reasonable to assume that the evolutionary development of a coccosphere was not an instant but a stepwise cumulative process, relying on random mutations, genetic drift, evolutionary/environmental constraints, and natural selection. One pre-requisite of intracellular calcification is the accumulation of $\mathrm{Ca}^{2+}$ and $\mathrm{CO}_{3}^{2-}$ in a defined space to induce precipitation of calcium carbonate. The biological control of intracellular precipitation is vital as uncontrolled inorganic crystal growth can lead to rupture of biomembranes and ultimately to cell death. The transport to and the accumulation of ions at the site of precipitation in conjunction with the physiological precipitation control of the carbonate crystal can be determined as the first essentials for intracellular coccolith genesis and development. These seemingly simple requisites involve the development of a successful interplay of cellular biochemistry, such as the presence of specialized ion transport/pumping mechanism and the production and distribution of organic compounds capable to direct and/or inhibit crystal growth. These intermediate evolutionary first steps of intracellular calcification have been likely developed over a significant time frame and were subject to natural selection. Hypothetically, molecular data suggest that the ability of coccolithophores to calcify evolved well before the first record of fossil coccoliths (Liu et al., 2010) which seems a logical prerequisite. The detection of fossil evidence to prove intermediate evolutionary steps is presumably not trivial because of (1) the lack of well-preserved pelagic sediments older than $150 \mathrm{Ma}$ (Bown et al., 2004) and (2) a low preservation of coccoliths in the deep ocean. Furthermore, it is feasible that coccolith precursors were derived from amorphous calcium carbonate phases which avoids certain limitations induced by the crystallographic dependent orientation or anisotropy of $\mathrm{CaCO}_{3}$ and allows to shape and to direct the mineral phase in an early stage of evolutionary development (Addadi et al., 2003). Amorphous calcium carbonates, however, are easily overlooked in fossil samples due to their low birefringence or double refraction in comparison to calcite, complicating an easy detection in fossil samples.

The intermediate evolutionary first steps of intracellular calcium carbonate precipitation, such as amorphous calcium carbonates and basic developed coccoliths, likely resulted in incomplete $\mathrm{CaCO}_{3}$ cell cover and a low calcium carbonate to organic carbon ratio. This implies that a protective function was not achieved at the initiation of the calcification process and coccolith genesis. Therefore, the explanation that calcification evolved initially as a protective function or to reduce grazing pressure seems to be goal directed or teleological. This is problematic because it suggests a backwards causality, moving from the future to the past, and describing the appearance or initiation of calcification to be caused by an end function of coccoliths. Therefore, we need to consider the possibility that the historical genesis of calcification in coccolithophores served a quite different function and benefits compared to modern ecological settings. Such an evolutionary feature has been coined exaptation, a trait that now enhances fitness but was not shaped by natural selection because of its current function (Gould and Vrba, 1982). This opens the opportunity to separate possible benefits of coccolithophore calcification into two groups: (1) its end-benefits depending on the prevailing ecological settings and (2) its historical benefits at the time of the stepwise development of intracellular calcification and the genesis of coccoliths. For the latter case, the evolutionary benefits subject to natural selection must be associated with the biochemical process of calcification and not with the final end-product, namely the coccolith or the complete coccosphere.

Two hypotheses have been proposed addressing biochemical benefits of intracellular calcium fixation into the biological inert form of $\mathrm{CaCO}_{3}$ : (1) avoiding intracellular precipitation of $\mathrm{HPO}_{4}$ or phosphate esters (Raven and Crawfurd, 2012) and (2) maintaining cellular calcium homeostasis and avoiding toxic intracellular $\mathrm{Ca}^{2+}$ concentrations (Kazmierczak et al., 2013; Müller et al., 2015). These two mechanisms theoretically provide cellular benefits with the first calcium ion precipitated by avoiding precipitation of intracellular phosphate, a nutrient necessary for growth and organic matter production, or by regulating cytosol $\mathrm{Ca}^{2+}$ homeostasis, respectively. In distinction to other hypotheses, these two propositions focus on benefits gained by the process of calcification and not by the final end product. Thus, the final structure or morphological diversity 
TABLE 1 | Two categories of calcification-hypotheses addressing the possible functions and benefits of biomineralization in coccolithophores.

\begin{tabular}{ll}
\hline Process benefits & References \\
\hline $\begin{array}{l}\text { Avoidance of intracellular phosphate precipitation } \\
\text { Intracellular } \mathrm{Ca}^{2+} \text { control and detoxification }\end{array}$ & $\begin{array}{l}\text { Raven and Crawfurd, 2012 } \\
\text { Kazmierczak et al., 2013; Müller et al., 2015 }\end{array}$ \\
\hline End-product benefits & References \\
\hline Ballasting to reach different depth for nutrient acquisition & Paasche, 2001; Raven and Waite, 2004 \\
Grazing protection & Nejstgaard et al., 1994; Harvey et al., 2015; Monteiro et al., 2016 \\
Light bundling to support photosynthesis at low light conditions & Young, 1994 \\
UV- and photoprotection & Braarud and Nordli, 1952; Gao et al., 2009; Barcelos e Ramos et al., 2012 \\
Virus protection & Raven and Waite, 2004; Mackinder et al., 2009
\end{tabular}

of coccoliths is of secondary importance in this context. First experimental evidence suggests that the ability to calcify provides an efficient mechanism for intracellular $\mathrm{Ca}^{2+}$ detoxification which would be of advantage at geological times of elevated seawater $\mathrm{Ca}^{2+}$ concentrations (e.g., Cretaceous and Jurassic) in comparison to the relatively low modern oceanic concentration (Müller et al., 2015).

The highly ornate physical structures of coccoliths are impressive and it is puzzling how and why they have evolved in this diversity. In the light of adaptive evolution and natural selection, the high diversity of coccoliths, as seen in the sediment record and the modern ocean, can be partly explained by small differences in physicochemical conditions, environmental forcing, and associated organic matrices during the historical genesis of calcification. Small environmental differences during stepwise evolution of intracellular calcification could have led to considerable differences in the evolutionary downstream development, resulting in a high morphological diversity. In fact, amorphous calcium structures, as for example found in cyanobacteria (Couradeau et al., 2012) and recently in coccolithophores (Sviben et al., 2016), can be easily influenced in their crystallization patterns by altered physicochemical conditions (Kellermeier et al., 2010). It is reasonable to assume that the organic compounds and matrices involved in regulating crystal growth (e.g., Gal et al., 2016) have been modified, corrected, and reorganized multiple times with independent origins depending on environmental forcing and constraints. Indeed, different and species specific polysaccharides have been identified to be involved in regulating $\mathrm{CaCO}_{3}$ precipitation, growth, and organization (De Jong et al., 1976; Corstjens et al., 1998; Walker et al., 2018a).If the diversity of the organic machinery involved in coccolithogenesis can be related to crystallographic (aragonite and calcite) and structural differences (nannoliths, holo- and heterococcoliths) remains to be tested. Here, I purpose to classify the diverse hypotheses addressing the function of coccolithophore calcification into two groups: (1) benefits due to the calcification process and (2) secondary benefits of the completed end-product (Table 1). The combination of these possible benefits and functions has presumably secured this cellular biomineralization mechanism through diverse ecological and physicochemical settings over the geological past.

In a recent study, Walker et al. (2018b) demonstrated in laboratory experiments, where grazing and other unfavorable environmental conditions were excluded, that the process of calcification is an important physiological trait whose disturbance can result in diminished cellular replication/growth rates of Coccolithus braarudii. Emiliania huxleyi, on the other hand, did not demonstrated decreased growth rates when the process of calcification was artificially reduced. These results clearly demonstrate that the benefits of calcification in coccolithophores can be species specific and thus care needs to be taken when testing hypothesis on only one coccolithophore species. Future endeavors and research on coccolithophore biomineralization should take into account the differentiation between (1) the biological end functions that can be assigned to calcification under various ecological settings (e.g., low light conditions, grazing pressure, UV-radiation, etc.) and (2) the process benefits of biomineralization genesis and development. An increasing number of hypotheses will certainly broaden our horizons to develop new and strong concepts regarding intracellular calcification of phytoplankton. On a broader context, the differentiation between process benefits of biocalcification and its secondary functions is a valuable line of thought to discuss and to explain the onset and evolution of biomineralization throughout Earth history. For example, the rise in $\mathrm{Ca}^{2+}$ concentrations in the shelf sea at the Precambrian/Cambrian boundary has been related to $\mathrm{Ca}^{2+}$ detoxification, regulation, and the subsequent development of calcareous structures in protists and invertebrates (Simkiss, 1977; Kazmierczak et al., 2013). However, it should be stressed that biocalcification is only one out of many possible mechanisms to regulate intracellular $\mathrm{Ca}^{2+}$ concentrations and that the biochemical "end-product" encounters natural selection and a diverse array of evolutionary pressures which ultimately results in adaptive evolution. I hope that my thoughts expressed here will encourage students and researchers to develop projects addressing these peculiar, urgent, and basic issues of coccolithophore biology. 


\section{AUTHOR CONTRIBUTIONS}

The author confirms being the sole contributor of this work and has approved it for publication.

\section{REFERENCES}

Addadi, L., Raz, S., and Weiner, S. (2003). Taking advantage of disorder: amorphous calcium carbonate and its roles in biomineralization. Adv. Mater. Weinheim. 15, 1-12. doi: 10.1002/adma.200300381

Balch, W. M. (2018). The Ecology, biogeochemistry, and optical properties of coccolithophores. Annu. Rev. Mar. Sci. 10, 71-98. doi: 10.1146/annurev-marine-121916-063319

Barcelos e Ramos, J., Schulz, K. G., Febiri, S., and Riebesell, U. (2012). Photoacclimation to abrupt changes in light intensity by Phaeodactylum tricornutum and Emiliania huxleyi: the role of calcification. Mar. Ecol. Prog. Ser. 452, 11-26. doi: 10.3354/meps09606

Bown, P. R., Lees, J. A., and Young, J. R. (2004). "Calcareous nannoplankton evolution and diversity through time," in Coccolithophores-From Molecular Processes to Global Impact, eds H. R. Thierstein and J. R. Young (New York, NY: Springer), 481-508.

Braarud, T., and Nordli, E. (1952). Coccoliths of Coccolithus huxleyi seen in an electron microscope. Nature 170, 361-362. doi: 10.1038/170361a0

Brownlee, C., Wheeler, G. L., and Taylor, A. R. (2015). Coccolithophore biomineralization: new questions, new answers. Semin. Cell. Dev. Biol. 46, 11-16. doi: 10.1016/j.semcdb.2015.10.027

Corstjens, P. L. A. M., Van der Kooij, A., Linschooten, C., Brouwers, G.-J., Westbroek, P., and de Vrind-de Jong, E. W. (1998). GPA, a calcium-binding protein in the coccolithophorid Emiliania huxleyi (Prymnesiophyceae). J. Phycol. 43, 622-630. doi: 10.1046/j.1529-8817.1998.340622.x

Couradeau, E., Benzerara, K., Gérard, E., Moreira, D., Bernard, S., Brown, G. E., et al. (2012). An early-branching microbialite cyanobacterium forms intracellular carbonates. Science 336, 459-462. doi: 10.1126/science.1216171

De Jong, E. W., Bosch, L., and Westbroek, P. (1976). Isolation and characterisation of a $\mathrm{Ca}^{2+}$-binding polysaccharide associated with coccoliths of Emiliania huxleyi (Lohmann) Kamptner. Eur. J. Biochem. 70, 611-621. doi: 10.1111/j.1432-1033.1976.tb11052.x

de Vargas, C., Aubry, M.-P., Probert, I., and Young, J. (2007). "Origin and evolution of coccolithophores: from coastal hunters to oceanic farmers," in Evolution of Primary Producers in the Sea, eds P. G. Falkowski and A. Knoll (London: Elsevier Academic Press), 441.

Gal, A., Wirth, R., Kopka, J., Fratzl, P., Faivre, D., and Scheffel, A. (2016). Macromolecular recognition directs calcium ions to coccolith mineralization sites. Science 353, 590-593. doi: 10.1126/science.aaf7889

Gao, K., Ruan, Z., Villafane, V. E., Gattuso, J. P., and Helbling, E. W. (2009). Ocean acidification exacerbates the effect of UV radiation on the calcifying phytoplankter Emiliania huxleyi. Limnol. Oceanogr. 54, 1855-1862. doi: 10.4319/lo.2009.54.6.1855

Gould, S. J., and Vrba, E. S. (1982). Exaptation-a missing term in the science of form. Paleobiology 8, 4-15. doi: 10.1017/S0094837300004310

Harvey, E. L., Bidle, K. D., and Johnson, M. D. (2015). Consequences of strain variability and calcification in Emiliania huxleyi on microzooplankton grazing. J. Plankton Res. 37, 1137-1148. doi: 10.1093/plankt/fbv081

Hermoso, M. (2014). Coccolith-derived isotopic proxies in palaeoceanography: where geologists need biologists. Cryptogam. Algol. 35, 323-352. doi: 10.7872/crya.v35.iss4.2014.323

Hofmann, G. E., Barry, J. P., Edmunds, P. J., Gates, R. D., Hutchins, D. A., Klinger, T., et al. (2010). The effect of ocean acidification on calcifying organisms in marine ecosystems: an organism to-ecosystem perspective. Annu. Rev. Ecol. Evol. Syst. 41, 127-147. doi: 10.1146/annurev.ecolsys.110308.120227

Kazmierczak, J., Kempe, S., and Kremer, B. (2013). Calcium in the early evolution of living systems: a biohistorical approach. Curr. Org. Chem. 17, 1738-1750. doi: 10.2174/13852728113179990081

Kellermeier, M., Melero-García, E., Glaab, F., Klein, R., Drechsler, M., Rachel, R., et al. (2010). Stabilization of amorphous calcium carbonate in

\section{ACKNOWLEDGMENTS}

I am grateful for early suggestions and comments by Kai G. Schulz. Additionally, the fruitful discussions during the review process significantly improved this essay.

inorganic silica-rich environments. J. Am. Chem. Soc. 132, 17859-17866. doi: $10.1021 /$ ja106959p

Liu, H., Aris-Brosou, S., Probert, I., and de Vargas, C. (2010). A time line of the environmental genetics of the haptophytes. Mol. Biol. Evol. 27, 161-176. doi: 10.1093/molbev/msp222

Mackinder, L., Wheeler, G., Schroeder, D., von Dassow, P., Riebesell, U., and Brownlee, C. (2011). Expression of biomineralization-related ion transport genes in Emiliania huxleyi. Environ. Microbiol. 13, 3250-3265. doi: 10.1111/j.1462-2920.2011.02561.x

Mackinder, L. C., Worthy, C. A., Biggi, G., Hall, M., Ryan, K. P., Varsani, A., et al. (2009). A unicellular algal virus, Emiliania huxleyi virus, exploits an animal-like infection strategy. J. Gen. Virol. 90, 2306-2316. doi: 10.1099/vir.0.011635-0

McClelland, H. L., Bruggeman, J., Hermoso, M., and Rickaby, R. E. (2017). The origin of carbon isotope vital effects in coccolith calcite. Nat. Commun. 8:14511. doi: 10.1038/ncomms14511

Mejía, L. M., Paytan, A., Eisenhauer, A., Böhm, F., Kolevica, A., Bolton, $\mathrm{C}$, et al. (2018). Controls over $\delta^{44 / 40} \mathrm{Ca}$ and $\mathrm{Sr} / \mathrm{Ca}$ variations in coccoliths: New perspectives from laboratory cultures and cellular models. Earth Planet. Sci. Lett. 481, 48-60. doi: 10.1016/j.epsl.2017. 10.013

Monteiro, F. M., Bach, L. T., Brownlee, C., Bown, P., Rickaby, R. E., Poulton, A. J., et al. (2016). Why marine phytoplankton calcify. Sci. Adv. 2: e1501822. doi: $10.1126 /$ sciadv. 1501822

Müller, M. N., Barcelos e Ramos, J., Schulz, K. G., Riebesell, U., Kazmierczak, J., Gallo, F., et al. (2015). Phytoplankton calcification as an effective mechanism to alleviate cellular calcium poisoning. Biogeosciences 12, 6493-6501. doi: 10.5194/bg-12-6493-2015

Müller, M. N., Krabbenhöft, A., Vollstaedt, H., Brandini, F. P., and Eisenhauer, A. (2018). Stable isotope fractionation of strontium in coccolithophore calcite: Influence of temperature and carbonate chemistry. Geobiology 16, 297-306. doi: $10.1111 /$ gbi.12276

Nejstgaard, J. C., Witte, H. J., Donderwal, P., and Jaconsen, A. (1994). Copepod grazing during a mesocosm study of an Emiliania huxleyi bloom. Sarsia 79, 369-377. doi: 10.1080/00364827.1994.10413568

Paasche, E. (2001). A review of the coccolithophorid Emiliania huxleyi (Prymnesiophyceae) with particular reference to growth, coccolith formation and calcification-photosynthesis interactions. Phycologia 40, 503-529. doi: 10.2216/i0031-8884-40-6-503.1

Raven, J. A., and Crawfurd, K. (2012). Environmental controls on coccolithophore calcification. Mar. Ecol. Prog. Ser. 470, 137-166. doi: 10.3354/meps09993

Raven, J. A., and Waite, A. M. (2004). The evolution of silicification in diatoms: inescapable sinking and sinking as escape? New Phytol. 162, 45-61. doi: 10.1111/j.1469-8137.2004.01022.x

Sanders, R., Morris, P. J., Poulton, A. J., Stinchcombe, M. C., Charalampopoulou, A., Lucas, M. I., et al. (2010). Does a ballast effect occur in the surface ocean? Geophys. Res. Lett. 37:L08602. doi: 10.1029/2010GL0 42574

Simkiss, K. (1977). Biomineralization and detoxification. Calc. Tiss. Res. 24, 199-200.

Sorby, H. C. (1861). On the organic origin of the so called "crystalloids" of the chalk. Ann. Mag. Nat. Hist. 8, 193-200.

Sviben, S., Gal, A., Hood, M. A., Bertinetti, L., Politi, Y., Bennet, M., et al. (2016). A vacuole-like compartment concentrates a disordered calcium phase in a key coccolithophorid alga. Nat. Commun. 7:11228. doi: 10.1038/ncomms11228

Taylor, A. R., Brownlee, C., and Wheeler, G. (2017). Coccolithophore cell biology: chalking up progress. Annu. Rev. Mar. Sci. 9, 283-310. doi: 10.1146/annurev-marine-122414-034032

Thomsen, H. A., and Østergaard, J. B. (2015). Coccolithophorids in polar waters: Trigonaspis spp. revisited. Acta Protozool. 54, 85-96. doi: 10.4467/16890027AP.15.007.2732 
von Dassow, P., and Montresor, M. (2011). Unveiling the mysteries of phytoplankton life cycles: patterns and opportunities behind complexity. J. Plankton Res. 33, 3-12. doi: 10.1093/plankt/f bq137

Walker, C. E., Heath, S., Salmon, D. L., Smirnoff, N., Langer, G., Taylor, A. R., et al. (2018a). An extracellular polysaccharide-rich organic layer contributes to organization of the coccosphere in coccolithophores. Front. Mar. Sci. 5:306. doi: 10.3389/fmars.2018.00306

Walker, C. E., Taylor, A. R., Langer, G., Durak, G. M., Heath, S., Probert, I., et al. (2018b). The requirement for calcification differs between ecologically important coccolithophore species. New Phytol. 220, 147-162. doi: $10.1111 / \mathrm{nph} .15272$

Young, J. R. (1994). "Functions of coccoliths," in Coccolithophores, eds A. Winter, and W. G. Siesser (Cambridge: Cambridge University Press), 63-82.
Young, J. R., and Henriksen, K. (2003). Biomineralization within vesicles: the calcite of coccoliths. Rev. Mineral. Geochem. 54, 189-215. doi: 10.2113/05 40189

Conflict of Interest Statement: The author declares that the research was conducted in the absence of any commercial or financial relationships that could be construed as a potential conflict of interest.

Copyright (c) 2019 Müller. This is an open-access article distributed under the terms of the Creative Commons Attribution License (CC BY). The use, distribution or reproduction in other forums is permitted, provided the original author(s) and the copyright owner(s) are credited and that the original publication in this journal is cited, in accordance with accepted academic practice. No use, distribution or reproduction is permitted which does not comply with these terms. 